\title{
PENGEMBANGAN PERANGKAT PEMBELAJARAN BIOLOGI \\ BERBASIS RECIPROCAL TEACHINGUNTUK MELATIHKAN \\ KETERAMPILAN KOMUNIKASI DAN PEMAHAMAN KONSEP
}

\author{
Lili Suharli' ${ }^{1}$ Muslimin ${ }^{2}$, Thamrin ${ }^{3}$ \\ 1Mahasiswa Program Pascasarjana, Program Studi Pendidikan Sains, Universitas Negeri Surabaya \\ 2\&3 Dosen Pascasarjana Prodi Pendidikan Sains Universitas Negeri Surabaya
}

\begin{abstract}
ABSTRAK
Penelitian ini bertujuan untuk menghasilkan perangkat pembelajaran Biologi berbasis strategi Reciprocal teachingyang layak digunakan untuk melatihkan keterampilan komunikasi dan pemahaman konsep siswa. Pengembangan perangkat pembelajaran menggunakan model Dick and Carey, diujicobakan pada 30 siswa kelas XI IPA 2 dengan rancangan One Group Pretest-Postest Design. Kelayakan perangkat pembelajaran yang dikembangkan dianalisis secara deskriptif kuantitatif-kualitatif. Hasil validasi perangkat pembelajaran meliputi silabus, RPP, buku ajar siswa, lembar kegiatan siswa, tes hasil belajar, dan instrumen keterampilan komunikasi dengan kategori baik. Keterlaksanaan RPP menunjukkan 98\% terlaksana. Hasil analisis respon siswa menunjukkan bahwa 94\% siswa memberikan respon positif terhadap perangkat dan kegiatan pembelajaran yang diterapkan. Penerapan perangkat pembelajaran pada uji coba II menunjukkan peningkatan pada pemahaman konsep siswa berdasarkan tes hasil belajar aspek pengetahuan yang dianalisis menggunakan N-Gain sebesar 0.90. Selain itu, keterampilan komunikasi siswa mendapat predikat B (Baik). Kesimpulan penelitian ini, bahwa perangkat pembelajaran Biologi berbasis strategi Reciprocal teaching yang dikembangkan layak diterapkan dan dapat melatihkan keterampilan komunikasi dan pemahaman konsep.
\end{abstract}

Kata kunci : Perangkat Pembelajaran, Reciprocal Teaching, Keterampilan komunikasi, Pemahaman Konsep

\section{PENDAHULUAN}

Pendidikan adalah kebutuhan yang harus didapatkan oleh seluruh anak bangsa. Pendidikan bertujuan untuk menciptakan generasi penerus bangsa yang memiliki ketakwaan pada Tuhan Yang Maha Esa, berahlak mulia, berilmu, kreatif, inovatif, produktif dan bertanggung jawab. Keberhasilan tujuan pendidikan nasional menjadi syarat penting dalam meningkatkan sumber daya manusia demi tercapainya kemajuan negara. Faktanya bahwa kualitas pendidikan nasional di Indonesia belum dapat menunjukkan pencapaian tujuan pendidikan nasional. Hasil studi oleh PIRLS (Progress in International Reading Literacy Study), TIMMS (Trends in International Matematics and Science Study) dan PISA (Programme for International Student Assessment) menunjukkan bahwa kualitas pendidikan di Indonesia masih dalam peringkat rendah, sehingga perlu ada perubahan orientasi kurikulum dengan tidak membebani peserta didik dengan konten namun pada aspek keterampilan atau kemampuan esensial yang diperlukan oleh semua warga negara untuk berperan serta dalam membangun negara pada masa mendatang. Salah satu keterampilan yang harus dimiliki oleh peserta didik yaitu keterampilan komunikasi. Keterampilan komunikasi membantu peserta didik dalam menghadapi tantangan zaman.

Komunikasi adalah proses yang mengubah informasi antara seorang dengan seseorang lainnya melalui sistem penggunaan simbol, tanda maupun perilaku. Komunikasi menjadi kunci atau modal dalam lingkungan sosial dan pekerjaan atau karir untuk membangun dan menjalin hubungan baik antar sesama. Dalam konteks ini, maka keterampilan komunikasi harus dilatih, sebab berkomunikasi membutuhkan kemampuan (skill) yang perlu dikembangkan dan dilatih secara bertahap. Keterampilan komunikasi membantu seseorang agar dapat mengembangkan dan memberdayakan dirinya. Dalam berbagai bidang dan lingkungan, keterampilan komunikasi sangat penting guna menjalin hubungan yang baik. Pada lingkungan sekolah, penerapan komunikasi yang intensif dapat memacu perkembangan kecerdasan dan prestasi peserta didik. Jay Mctighe and Elliot seif (2003), berpendapat bahwa inti dari keberhasilan pendidikan sekolah dapat terlihat dari pemaknaan dan pemahaman. Bermakna dan pemahaman dapat terlihat jika 
siswa mampu menjelaskan serta mengintrepetasikan ide sesuai fakta, dan mampu membuat pertanyaan yang relevan, serta dapat mengaplikasikan pengetahuannya dalam kehidupan sehari-hari.

Menurut Bloom dalam Utari, (2011) pemahaman konsep adalah keterampilan dalam menjelaskan suatu arti atau makna. Keberhasilan siswa dalam memahami konsep akan memberikan dampak positif pada peningkatan prestasi siswa. Prestasi siswa meningkat pula dengan keterampilan siswa dalam berkomunikasi, hal ini menunjukkan bahwa keterampilan komunikasi dan pemahaman konsep saling berhubungan. Siswa yang terampil dalam komunikasi di kelas menunjukkan bahwa siswa memahami konsep dan siswa yang memahami konsep akan terampil dalam berkomunikasi dalam kegiatan belajar di kelas.

Penggunaan strategi Reciprocal teaching dalam pembelajaran meningkatkan kemampuan kognitif dan metakognitif siswa, seperti kemampuan komunikasi serta pemahaman konsep. Hal ini dikarenakan dalam strategi Reciprocal teaching terdiri dari empat prinsip yaitu bertanya (Questioning), dan merangkum (Summarizing), memprediksi (Predicting), mengklarifikasi (Clarifying). Reciprocal teaching adalah pendekatan konstruktivis yang didasarkan pada prinsip-prinsip membuat pertanyaan, mengajarkan keterampilan metakognitif melalui pengajaran dan permodelan oleh guru untuk meningkatkan keterampilan membaca pada siswa yang berkemampuan rendah (Ibrahim, 2008). Ke empat prinsip dalam strategi Reciprocal teaching dapat melatihkan keterampilan komunikasi siswa melalui kegiatan diskusi, representasi, mendengar, menulis, dan membaca. Siswa akan diajarkan membuat pertanyaan berkaitan dengan materi yang telah dibaca, dan merangkum informasi-informasi yang dianggap penting, selain itu mengkarifikasi istilah-istilah dalam bacaan serta memprediksi bacaan berikutnya menandakan bahwa siswa melakukan kegiatan berpikir tingkat tinggi sehingga meningkatkan pemahaman konsep siswa (King, 2014).

Berdasarkan uraian tersebut maka dilakukan wawancara pada guru biologi SMA di Lamongan, dari sumber tersebut diketahui bahwa secara umum guru memberikan model pembelajaran di kelas dengan metode ceramah, sehingga peserta didik cendrung pasif. Siswa lebih banyak melakukan kegiatan mencatat dan mendengar penjelasan dari guru. Interaksi siswa yang kurang aktif dan penggunaan metode pembelajaran berbasis ceramah menjadi kurang efisien untuk mencapai tujuan pembelajaran yang ditetapkan. Tujuan pembelajaran disesuaikan dengan KI dan KD yang telah ditetapkan oleh Kemendikbud 2013. oleh karena itu berdasarkan uraian di atas dan dengan tuntutan pada KD 3.14 dan KD 4.17 mengenai materi sistem pertahanan tubuh, diharapkan siswa dapat mendeskripsikan dan mempresentasikan materi sistem pertahanan tubuh sehingga perlu dilakukan penelitian mengenai "pengembangan perangkat pembelajaran biologi berbasis strategi Reciprocal teaching untuk melatihkan keterampilan komunikasi dan pemahaman konsep pada materi sistem pertahanan tubuh.

\section{METODE PENELITIAN}

Penelitian ini merupakan suatu penelitian pengembangan (developmental research) dan bertujuan untuk menghasilkan perangkat pembelajaran biologi yang layak pada pokok bahasan sistem pertahanan tubuh berorientasi strategi Reciprocal Teaching. Penelitian diujicobakan di kelas XI IPA 2 menggunakan desain pra-ekperimen (one group pretestpostest design dengan menggunakan pengembangan pembelajaran model Dick \& Carey (1990). Tahapan-tahapan pada model Dick dan Carey dapat dilihat pada Gambar 1. di bawah ini:

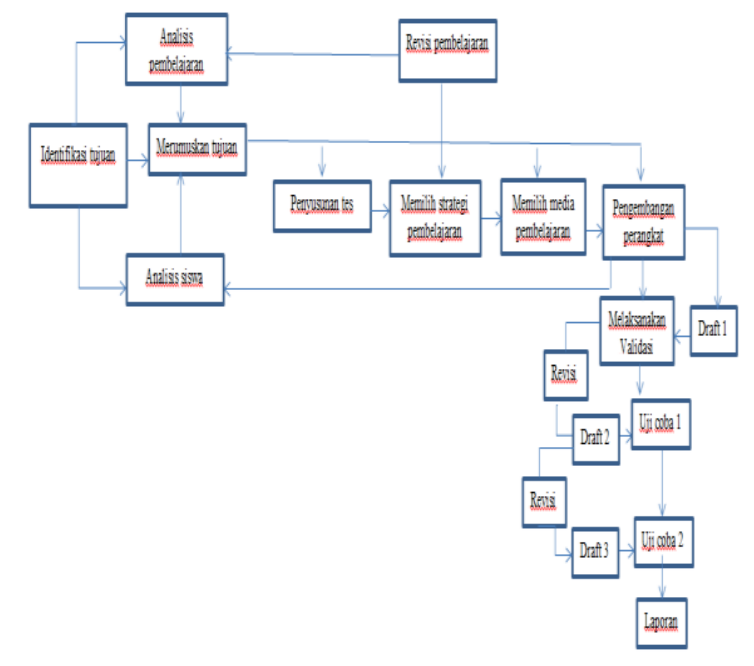

Gambar 1. Skema Alur Pengembangan Pembelajaran

Sumber: Diadaptasi dari Dick,W. dan Carey, L., (1990). 
Subyek penelitian ini adalah perangkat pembelajaran biologi yang dikembangkan berbasis strategi Reciprocal Teaching. Penelitian dilakukan dengan $2 \mathrm{x}$ uji coba, pada uji coba I menggunakan 15 siswa dan pada uji coba II digunakan 30 siswa kelas XI IPA 2 SMA Negeri 1 Paciran Lamongan tahun ajaran 2014-2015. Seluruh perangkat yang dikembangkan divalidasi oleh dua ahli sesuai dengan bidang terkait. Teknik dalam pengambilan data dilakukan dengan pemberian tes, respon serta melalui observasi. Materi yang dikembangkan yaitu materi sistem pertahanan tubuh pada kelas XI.

\section{HASIL DAN PEMBAHASAN}

Tujuan dari penelitian ini yaitu untuk memperoleh perangkat pembelajaran biologi berbasis strategi Reciprocal Teaching untuk melatihkan keterampilan komunikasi dan pemahaman konsep. Perangkat pembelajaran yang dikembangkan meliputi silabus, Rencana Pelaksanaan Pembelajaran (RPP), Buku Ajar Siswa (BAS), Lembar Kegiatan Siswa (LKS), Tes Hasil Belajar (THB), dan instrumen keterampilan komunikasi siswa. Menurut Supriyono (2014), perangkat pembelajaran yang dikembangkan dapat dikatakan layak dan baik jika perangkat tersebut mencangkup tiga aspek yaitu valid, praktis dan efektif.

Hasil validasi oleh ahli menentukkan validitas perangkat yang dikembangkan, sedangkan kepraktisan dapat diketahui melalui data hasil observasi keterlaksanaan RPP dan aspek efektif dapat diketahui melalui persentase ketuntasan belajar siswa serta keterampilan komunikasi siswa yang meningkat berdasarkan data hasil belajar pengetahuan dan keterampilan siswa. Respon siswa.terhadap pembelajaran serta perangkat yang diimplementasikan dapat menunjukkan keefektifan perangkat pembelajaran yang dikembangkan.

\section{A. Validitas Perangkat Pembalajaran}

Perangkat pembelajaran yang dikembangkan pada penelitian ini telah dianalisis dan menunjukkan hasil valid. Validasi dilakukan pada perangkat pembelajaran yang dikembangkan yaitu silabus dengan skor 3.4 dikategorikan valid, RPP terdiri dari empat kali pertemuan mendapat skor 3.8 dikategorikan valid, LKS memperoleh skor vaidasi 3.3 dengan berkategori valid. LKS dikembangkan menggunakan strategi Reciprocal Teaching melalui kegiatan-kegiatan seperti menuliskan ide pokok pada setiap paragraf, membuat pertanyaan dari teks yang dibaca, merangkum hal-hal penting dari bacaan, mengklarifikasi hal-hal kurang jelas atau tidak dipahami, dan memprediksi materi selanjutnya.

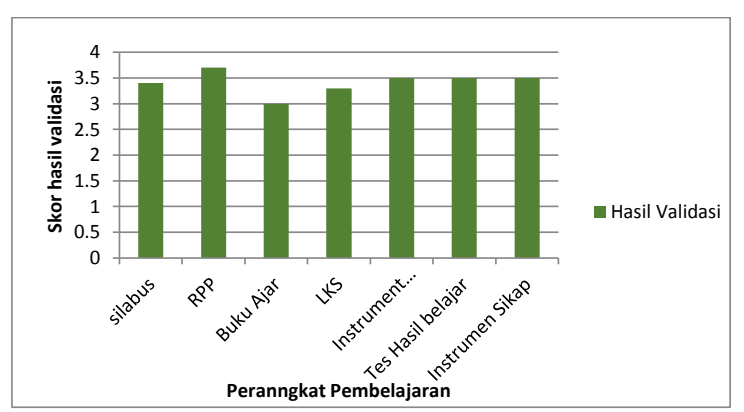

Gambar 2. Hasil Validasi Perangkat Pembelajaran

Skor hasil validitas THB adalah 3.5 dengan kategori valid. THB diukur dengan meninjau pada dua aspek yaitu kesesuaian isi materi yang dikembangkan serta bahasa dan penulisan soal yang benar. Instrumen yang digunakan untuk menilai keterampilan komunikasi siswa menunjukkan skor 3.5 dikategorikan valid sehingga dapat digunakan untuk menilai keterampilan komunikasi siswa.

\section{B. Kepraktisan Perangkat Pembelajaran}

Hasil analisis keterlaksnaan RPP menunjukkan bahwa keempat RPP yang dikembangkan oleh peneliti terlaksana dengan baik. Hasil keterlaksanaan RPP ini dapat digunakan untuk mengetahui kepraktisan suatu perangkat pembelajaran (Sulistyaningsih, 2002). RPP yang dikembangkan berisikan kegiatankegiatan pembelajaran yang akan dilakukan oleh siswa dengan mengikuti tahapan dalam strategi Reciprocal teaching untuk melatihkan keterampilan komunikasi dan pemahaman konsep siwa.

\section{Keterlaksanaan Pebelajaran}

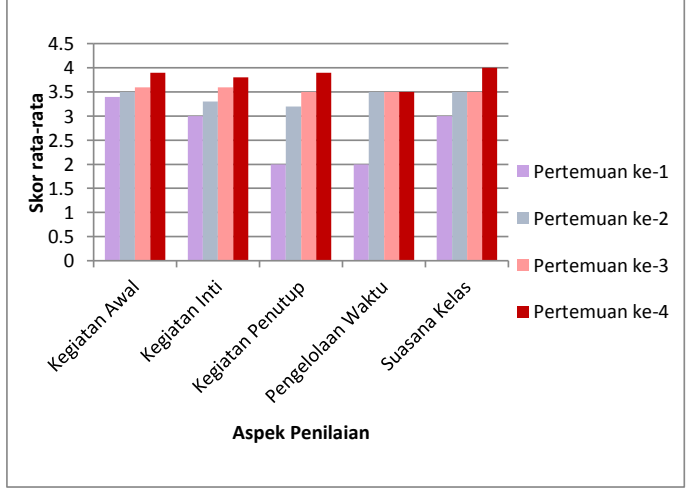


Gambar 3. Hasil Pengamatan Keterlaksanaan

Pembelajaran Biologi berbasis Reciprocal teaching

RPP digunakan oleh guru sebagai acuan untuk mengarahkan aktivitas siswa pada proses pembelajaran yang disesuaikan dengan menggunakan metode pembelajaran yang ingin diterapkan. Kegiatan pembelajaran pada penelitian ini mengikuti tahapan pembelajaran dalam startegi Reciprocal teaching. Penggunaan strategi Reciprocal teaching pada kegiatan pembelajaran dilakukan untuk dapat melatihkan keterampilan komunikasi dan pemahaman konsep siswa. Ke empat RPP yang dikembangkan merupakan pengembangan dari materi sistem pertahanan tubuh yang mengacu pada silabus. RPP yang dikembangkan berisi KI, KD, tujuan, materi, metode, media, langkah-langkah (pendahuluan, inti, dan penutup), dan penilaian pembelajaran.

Hasil analisis data pengamatan keterlaksanaan RPP pada pertemuan pertama hingga pertemuan ke empat menjadi acuan untuk mengetahui kepraktisan perangkat pembelajaran. Perangkat pembelajaran yang digunakan dalam proses belajar seperti LKS serta buku siswa dapat digunakan untuk melatihkan keterampilan komunikasi dan pemahaman konsep siswa. LKS berisi kegiatan yang mengarahkan siswa untuk mencari informasi melalui kegiatan membuat pertanyaan, mencari jawaban dari pertanyaan, membuat rangkuman dari bacaan, mengklarifikasi hal-hal yang belum dipahami dan memprediksi materi selanjutnya. Penerapan kegiatan dalam LKS ini merupakan prinsip dari metode pembelajaran Reciprocal teaching. Penerapan pembelajaran strategi Reciprocal teaching melalui kegiatan mencari dan mengolah informasi menjadikan siswa tidak hanya mengingat namun siswa dapat memahami konsep-konsep pada materi yang diajarkan (Effendi, 2014).

Strategi Reciprocal teaching dapat melatih keterampilan komunikasi siswa melalui kegiatan membaca, menulis, mendengar, diskusi, dan presentasi (Baroody, 2000). Keseluruhan kegiatan untuk melatihkan keterampilan komunikasi dicantumkan dalam langkah-langkah pembelajaran yang terdapat didalam RPP yang dikembangkan. Langkah-langkah pembelajaran yang terdapat dalam RPP melalui diskusi kelompok kecil (4-5 siswa) pada kegiatan inti serta presentasi hasil diskusi pada akhir kegiatan membantu siswa untuk berlatih komunikasi siswa melalui mengungkapkan ide dan pendapat serta menanggapi pertanyaan dari siswa lainnya.

\section{Respon Siswa}

Data tanggapan atau pendapat siswa mengenai perangkat pembelajaran yang diimplementasikan, metode yang digunakan dalam pembelajaran, dan cara guru dalam menyampaikan materi pembelajaran dianalisis melalui angket respon siswa. Angket respon siswa diberikan pada seluruh siswa pada akhir dari pertemuan. Penilaian siswa terhadap model pembelajaran dan perangkat pembelajaran melalui angket respon siswa dalam bentuk respon positif atau negatif. Angket respon siswa berisi pertanyaan-pertanyaan mengenai pendapat siswa terhadap perangkat pembelajaran yang digunakan dan metode yang diterapkan dalam kegiatan pembelajaran.

Pendapat yang diberikan siswa melalui angket respon siswa dapat berupa ketertarikan dan keterbaruan siswa terhadap model pembelajaran dan perangkat pembelajaran yang digunakan di dalam kelas. Informasi yang didapatkan melalui pemberian angket respon siswa terhadap perangkat pembelajaran seperti LKS dan buku siswa atau model pembelajaran yang berbasis Reciprocal teaching dapat menentukan kepraktisan dari perangkat pembelajaran yang dikembangkan. Sebanyak 94\% siswa memberikan respon positif terhadap penggunaan strategi Reciprocal teaching.

Hal ini dikarenakan siswa merasa baru terhadap model pembelajaran yang digunakan dan merasa tertarik untuk menggunakannya dalam pembelajaran materi lainnya.

\section{Kefektifan Perangkat Pembelajaran}

Aspek ketiga dari penilaian kelayakan perangkat pembelajaran yang dikembangkan untuk diimplementasikan yaitu keefektifan perangkat pembelajaran. Keefektifan perangkat pembelajaran biologi berbasis strategi Reciprocal teaching untuk melatihkan keterampilan komunikasi dan pemahaman konsep siswa dapat diketahui melalui tes hasil belajar pengetahuan untuk mengetahui pemahaman konsep siswa terhadap materi sistem pertahanan tubuh dan keterampilan komunikasi melalui pengamatan keterampilan siswa selama kegiatan pembelajaran berlangsung.

\section{Hasil Tes Pengetahuan Siswa}

Tes yang diberikan kepada siswa untuk mengetahui pemahaman siswa terhadap materi 
pembelajaran yang diberikan yaitu melalui pretest dan posttest. Hasil dari pretest dan posttest dianalisis menggunakan Normalized gain score (n-gain). Analisis menggunakan $n$-gain dilakukan untuk mengetahui peningkatan pengetahuan siswa sebelum penggunaan strategi Reciprocal teaching dan sesudah siswa menggunakan strategi Reciprocal teaching. Gain skor ternormalisasi menunjukkan tingkat efektivitas perlakuan dari pada perolehan skor.

Tes pemahaman konsep siswa dengan menggunakan 35 soal yang terdiri dari 30 soal pilihan ganda dan 5 soal uraian. Tes pemahaman konsep siswa terhadap materi sistem pertahanan tubuh dikembangkan dengan acuan beberapa indikator pemahaman konsep yaitu mampu menginterpretasi, memberikan contoh, mengklasifikasikan, merangkum, menduga, membandingkan, serta menjelaskan (Wiggins and McTighe, 1998). Hasil analisis pretest dan posttest 30 siswa kelas XI IPA 2 digambarkan sebagai berikut:

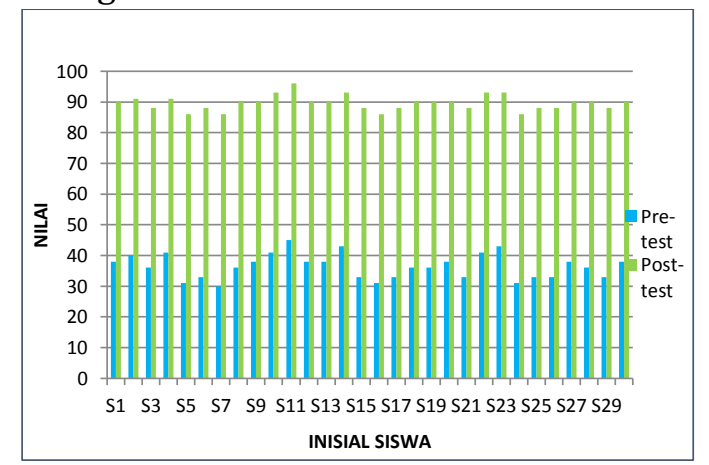

Gambar 4. Diagram Hasil pretest dan posttest siswa kelas XI IPA 2

Tujuan pembelajaran menjadi acuan pembuatan tes hasil belajar siswa yang dikembangkan dari indikator pembelajaran. Indikator pembelajaran merupakan penjabaran dari kompetensi inti dan kompetensi dasar pada materi sistem pertahanan tubuh (Depdiknas, 2006). Indikator yang digunakan dalam penelitian ini sebanyak 10 indikator dan dianalisis untuk mengetahui ketuntasan indikator pembelajaran. Hasil analisis ketuntasan indikator pembelajaran digambarkan sebagai berikut:

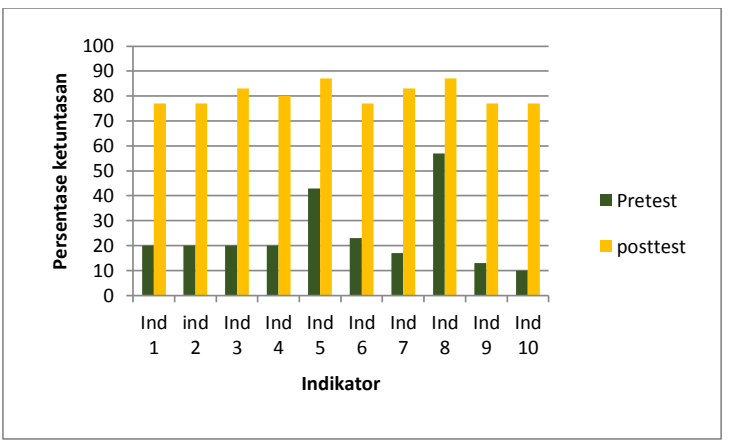

Gambar 5. Ketuntasan Indikator Tes Hasil Belajar Aspek Pengetahuan Siswa

Berdasarkan gambar 4 dan 5 maka dapat diketahui bahwa siswa kelas XI IPA 2 tuntas secara klasikal sebesar $100 \%$ pada posttest. Peningkatan pada hasil belajar siswa aspek pengetahuan berdasarkan hasil analisis perhitungan dengan menggunakan $\mathrm{N}$-gain dan memperoleh hasil sebesar 0,89 sehingga termasuk dalam kriteria tinggi. Hal ini menunjukkan bahwa setelah menerapkan perangkat pembelajaran biologi berbasis Reciprocal teaching hasil belajar pengetahuan siswa meningkat. Peningkatan hasil belajar siswa menjadi patokan untuk menilai pemahaman konsep siswa. Siswa dengan pemahaman konsep yang baik dapat menyelesaikan soal-soal pada instrumen penilaian hasil belajar aspek pengetahuan (Hongen et al, 1999).

Gambar 5 menunjukkan bahwa 10 indikator pembelajaran yang digunakan pada penelitian ini telah tuntas. Satu indikator dikatakan tuntas ika persentase $(\mathrm{P})$ siswa yang mencapai indikator tersebut sebesar $\geq 75 \%$. Hasil analisis ketuntasan indikator diketahui bahwa persentase rata-rata ketuntasan indikator pretest sebesar 24\% sehingga termasuk dalam kategori tidak tuntas, sedangkan pada hasil rerata persentase ketuntasan indikator posttest sebesar 80\% sehingga termasuk dalam kategori tuntas. Ketuntasan indikator diperoleh setelah siswa menerapkan strategi Reciprocal teaching. Menurut Efendi, 2014 yang menyatakan bahwa pengajaran dengan menerapkan strategi Reciprocal teaching efektif untuk meningkatkan dan menuntaskan hasil belajar siswa serta menjadikan siswa menjadi pembelajar yang aktif dan mandiri. Selaras dengan hal itu Hartati dkk, (2007: 7) mengungkapkan bahwa siswa mandiri menganggap bahwa kegiatan belajar merupakan sesuatu yang penting dan dapat meningkatkan prestasi di sekolah, sehingga siswa tidak terbebani saat kegiatan belajar.

Penerapan strategi Reciprocal teaching dapat melatihkan keterampilan komunikasi siswa. Menurut Muijs (2008), mengungkapkan bahwa 
mengutarakan dan menyampaikan ide dalam kegiatan pembelajaran menunjukkan keterampilan komunikasi yang baik. Mengungkapkan ide atau pendapat dapat dilakukan jika siswa mengetahui konsep dari suatu materi, hal ini sesuai dengan pernyataan Hongen et al (1999) bahwa kegiatan berdiskusi melalui bimbingan guru dapat meningkatkan penalaran siswa, sedangkan siswa yang melakukan kegiatan diskusi dengan teman sebaya dapat meningkatkan pemikiran generatif dan eksploratif. Keterampilan komunikasi siswa diamati oleh dua pengamatan dan data hasil pengamatan dianalisis untuk mengetahui keterampilan komunikasi siswa. Hasil analisis keterampilan komunikasi siswa digambarkan sebagai berikut:

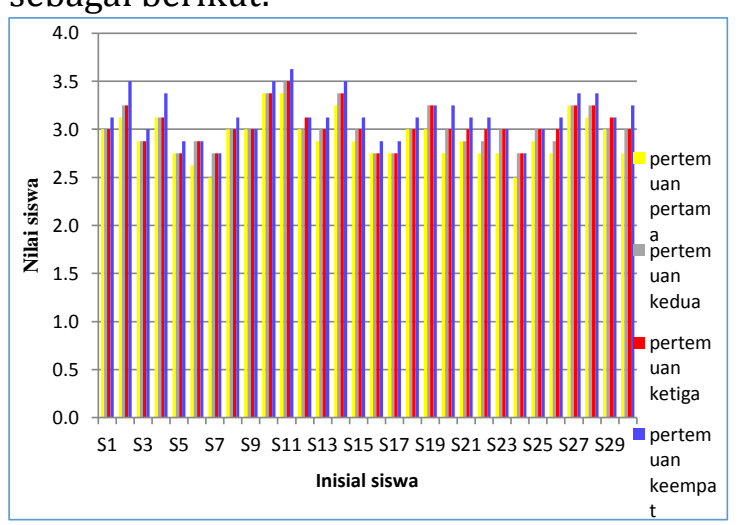

Gambar 6. Hasil Analisis Keterampilan

Komunikasi Siswa Pada Setiap Pertemuan

Gambar 6. di atas menunjukkan bahwa 30 siswa kelas XI IPA 2 mendapat skor rerata 3 sehingga dikategorikan baik. Komunikasi merupakan proses pengiriman informasi. Pesan atau informasi yang diterima dengan baik dan dapat dipahami oleh penerima pesan dari pemberi pesan pesan menunjukkan bahwa komunikasi yang terjadi antara pemberi pesan dan penerima pesan telah berhasil. Keterampilan komunikasi yang dilatihkan melalui penerapan pembelajaran strategi Reciprocal teachingterjadi dengan cara siswa membuat pertanyaan dan mengomentari pertanyaan temannya baik melalui kegiatan diskusi maupun presentasi. Pernyataan ini didukung oleh Muijs (2008) bahwa kerja dalam kelompok dapat membantu siswa dalam mengembangkan keterampilan partisipasi (Participation skills), keterampilan berbagi (Sharing skills), dan keterampilan komunikasi (Communication skills).

Ibrahim (2008) mengungkapkan bahwa pengajaran dengan startegi Reciprocal teaching menunjukkan hasil yang beragam, namun dapat memberikan pengaruh positif terhadap keterampilan komunikasi siswa. Kegiatan pembelajaran menggunakan strategi Reciprocal teaching seperti membuat pertanyaan dan menjawab pertanyaan dari temannya adalah kegiatan yang dapat berpengaruh positif terhadap keterampilan komunikasi selama kegiatan pembelajaran.

Keterampilan komunikasi siswa dapat diamati pada setiap pertemuan melalui kegiatan diskusi dan presentasi. Indikator yang digunakan untuk mengamati keterampilan komunikasi terdiri dari empat indikator diantara yaitu (1) ide disampaikan dengan jelas, singkat, mudah dipahami dan tahap demi tahap serta secara persuasif, (2) volume suara lantang, berbicara dengan jelas, dan menunjukkan ekspresi semangat, (3) memberikan pertanyaan maupun tanggapan secara jelas, relevan dan dapat dipahami, (4) memperhatikan dan mendengarkan secara seksama ekspresi dan reaksi pembicara lain.

Keterampilan komunikasi pada siswa didukung dari kegiatan diskusi melalui LKS. Kegiatan LKS dengan menerapkan strategi Reciprocal teaching seperti menuliskan pertanyaan dan membuat jawaban dari pertanyaannya merupakan salah satu kegiatan komunikasi. Menulis adalah kegiatan untuk menyampaikan ide, gagasan dan pesan dengan menggunakan lambang grafis. Kegiatan menulis berkaitan erat dengan kemampuan berbahasa diantaranya yaitu kegiatan membaca, menyimak dan berbicara (Semi, 2007). LKS yang dikembangkan terdiri dari kegiatan membaca untuk menemukan ide-ide pokok dalam setiap paragraf teks bacaan yang diberikan. Dengan demikian siswa terlatih untuk mengembangkan kemampuan membaca dan menulis serta komunikasi siswa melalui diskusi. Suatu kelompok belajar yang dapat bekerjasama dengan baik seperti saling menghormati, berbagi tugas kelompok dan saling memberikan bantuan dalam menyelesaikan tugas bersama memberikan dampak positif pada kelompok

Dampak positif yang dapat diberikan dari kegiatan berdiskusi dengan menerapkan strategi Reciprocal teaching seperti mengemukan ide, menjawab pertanyaan, memberikan penjelasan dan melakukan prediksi yaitu dapat meningkatkan hasil belajar kognitif, motivasi, dan keterampilan komunikasi. Kegiatan belajar dengan menerapkan Reciprocal teaching, melatihkan siswa untuk dapat mengungkapkan ide-ide dalam bacaan, sehingga prestasi belajar siswa dapat meningkat. Hal ini sesuai dengan 
teori konstruktivis yaitu siswa menjadikan informasi menjadi miliknya sendiri agar informasi yang diterima dapat dipahami. Penerapan Reciprocal teaching melalui kegiatan membuat pertanyaaan dan membuat jawaban dari pertanyaanya sendiri melatihkan siswa untuk dapat menemukan informasi mereka sendiri sehingga siswa diberi kesempatan untuk dapat menerapkan strategi belajar mereka sendiri dengan menemukan jawaban pertanyaan yang dibuatnya (Slavin, 1994: 225 dalam effendi, 2014).

Palincsar dan Brown, (1993) melaporkan bahwa dengan penrapan pembelajaran Reciprocal Teaching meningkatkan kemampuan kognitif siswa yang terlihat dalam aktivitas berdiskusi di kelas. Reciprocal teaching adalah salah satu pembelajaran kooperatif, sehingga dapat meningkatkan keterampilan komunikasi siswa dan pertumbuhan kognisi siswa serta berguna untuk meningkatkan prestasi belajar siswa, sebab siswa akan saling bekerja sama dalam memahami materi yang disampaikan guru.

\section{SIMPULAN DAN SARAN}

\section{A. Simpulan}

Berdasarkan penelitian yang telah dilakukan dan hasil penelitian serta pembahasannya, maka dapat disimpulkan bahwa perangkat pembelajaran biologi berbasis strategi Reciprocal Teaching yang dikembangkan layak digunakan untuk melatihkan keterampilan komunikasi dan pemahaman konsep.

\section{B. Saran}

Berdasarkan hasil penelitian yang telah dilakukan, perlu diperhatikan persiapan dan pengelolaan waktu agar pembelajaran dapat terlaksana dengan baik.

\section{DAFTAR PUSTAKA}

Baroody, A.J. (1993). Problem Solving,

Reasoning and CommunicationK-8

Helping Children Think Mathematically. New York: Macmillan Publishing Company.

Depdiknas. (2004). Penyusunan Perangkat Pembelajaran. Jakarta: Depdiknas.

Dick, Walter and Carey Lou. 1990. The Systematic Design of instruction 3rd Ed, Includes Bibliographical References: USA

Efendi, N. 2014. Pendekatan Pengajaran Reciprocal Teaching Berpotensi Meningkatkan Ketuntasan Hasil Belajar Biologi Siswa SMA. Vol. 2, No. 1, Februari 2013: Halaman 84-97
Hartati, S., Muna, N.F dan Setyawan, I. 2007. Hubungan Antara Kemandirian Dengan Motif Berkompetisi Pada Siswa Kelas Vii Rintisan Sekolah Bertaraf Internasional. Online:http://eprints.undip.ac.id/11107 /1/Jurnalku.pdf/ diakses tanggal 03 Februari 2011

Ibrahim, M. (2005). Assesmen Berkelanjutan. Konsep Dasar, Tahapan Pengembangan dan Contoh. Surabaya: Unesa University Press

Ibrahim. M. 2008. Reciprocal Teaching (Pembelajaran Resiprok),(online), (sainsmuslimin.blogspot.com/....../pemb elajaran-sains.html-cached-similiar, diakses 15 Maret 2015). Johnson, David W., Roger T Johnson., \& Edythe Johnson Holubec. 1994. Cooperative Learning in the Classroom. Alexandria, VA: Association for Supervision and Curriculum Development

Kemendikbud. 2014. Konsep dan Implementasi Kurikulum 2013. Diakses online http://kemdikbud.go.id/kemdikbud/do kumen/Paparan/Paparan\%20Wamendi k.pdf. 30 Oktober 2014

Kilpatrick, J., Swafford, J., \& Findell, B. (Eds.). (2001). Adding it Up: Helping Children Learn Mathematics. Washington, DC: National Academy Press

King, F.J., Ludwika, G., and Faranak, R. 2014. Higher Order Thinking Skills. A publication of the Educational Services Program.http://www.cala.fsu.edu/files/ higher_order_thinking_skills.pdf diakses tanggal 20 maret 2015

Muijs, D dan Reynold, D. Effective Teaching. Teori dan Aplikasi. Pusaka Belajar: Yogyakarta

McTighe, J., and Elliott, S. 2003. Teaching For Meaning An Understanding. A Summary Of Underlying Theory And Research Educational Consultans. Pennsykvania Educational Leadersip Volume 24 Number 1.

Lederer, J.M. (2000). Reciprocal Teaching of Social Studies in Inclusive Elementary Classrooms. Journal of Learning Disabilities. 33(1), 91-106. Retrieved on October 23, 2007, from MEDLINE--OVID database.

Palincsar. A and Brown. A . 1984. Reciprocal Teaching of Comprehension-fostering and Comprehension-monitoring activities. Cognition and Instruction, 2, 117-175. 
Riduwan. (2010). Skala pengukuran variabelvariabel penelitian. Bandung: Alfabeta.

Rosenbaum, T. 2005. Effective Communication Skills for Highway and Public Works Officials. Cornell Local Roads Program 416 Riley-Robb Hall Ithaca. New York www.clrp.cornell.edu diakses tanggal 23 Maret 2015

Semi, Atar. 2007. Dasar-Dasar Keterampilan Menulis. Bandung: Angkasa

Sulistyaningsih, D., Waluya, S.B., Kartono. 2002. Model pembelajaran kooperatif tipe circ dengan pendekatan konstruktivisme untuk meningkatkan kemampuan koneksi matematik. Unnes Journal of Mathematics Education Research 1 (2).

http://journal.unnes.ac.id/sju/index.php/ ujmer

Slavin, Robert E. (1994). Cooperative Learning, Teori, Riset, dan Praktik(Terjemahan). Bandung: Nusa Media.

Utari, R. 2011. Taksonomi Bloom.Apa dan Bagaimana Menggunakannya. http://www.bppk.depkeu.go.id/webpkn/attach ments/766_1 Taksonomi\%20Bloom\%20\%20Retno-ok-mima.pdf diakses tanggal 20 maret 2015 
